\title{
A Case of New-Onset Lichen Planus after COVID-19 Vaccination
}

Vincenzo Picone $\cdot$ Gabriella Fabbrocini $\cdot$ Lorenzo Martora •

Fabrizio Martora (10)

Received: December 15, 2021 / Accepted: January 27, 2022 / Published online: February 15, 2022

(C) The Author(s) 2022

\section{ABSTRACT}

The COVID 19 vaccination campaign has been underway for about a year now, and there are now many skin reactions associated with the administration of these vaccines in the literature. In view of the forthcoming third dose, we believe it is important to report our experience.

Keywords: Lichen planus; COVID-19; SARSCoV-2; Vaccine

\section{Key Summary Points}

Lichen planus is an inflammatory dermatosis involving the skin and/or mucous membranes, of unknown etiology mediated by $\mathrm{T}$ lymphocytes.

It can be associated with numerous triggers, such as medications, infections (such as Hepatitis C), and vaccines.

There are currently few cases in the literature reporting a relationship between COVID 19 vaccination and the occurrence of lichen planus.

This is one of the first cases of lichen planus associated with the Moderna vaccine.
V. Picone · G. Fabbrocini · F. Martora ( $₫)$ Dermatology Unit, Department of Clinical Medicine and Surgery, University of Naples Federico II, Via Sergio Pansini 5, Naples, Italy e-mail: fabriziomartora92@libero.it

\section{Martora}

Local Heath Company of Salerno (ASL), Salerno, Italy

\section{INTRODUCTION}

In December 2020, the US Food and Drug Administration (FDA) approved the worldwide use of messenger RNA (mRNA)-based vaccines, Pfizer/BioNTech (BNT162b2) and Moderna (mRNA-1273), to address the COVID-19 pandemic. 
However, as the vaccination campaign continues and more and more people are being administered the vaccine, several vaccinationassociated skin manifestations poorly reported in the literature are encountered in clinical practice.

\section{CASE REPORT}

Here we report the case of an 81-year-old male patient who, 7 days after the Moderna vaccine, developed an itchy papular rash with typical aspects of lichen planus. The patient presented to our dermatology outpatient unit with a 1-week history of intense pruritic eruption. During history collection, the patient reported no notable comorbidities and no prior episodes of lichen planus (LP). Moreover, the patient was not routinely taking any medications and denied taking any drugs prior to the rash. He also denied correlation with any stressful event prior to the onset of manifestations. On dermatologic physical examination, diffuse purple and polygonal papules were found on the flexor region of the wrists, lumbosacral region, posterior surface of the thighs, and dorsal region of the feet (Fig. 1). On dermoscopy, Wickham's

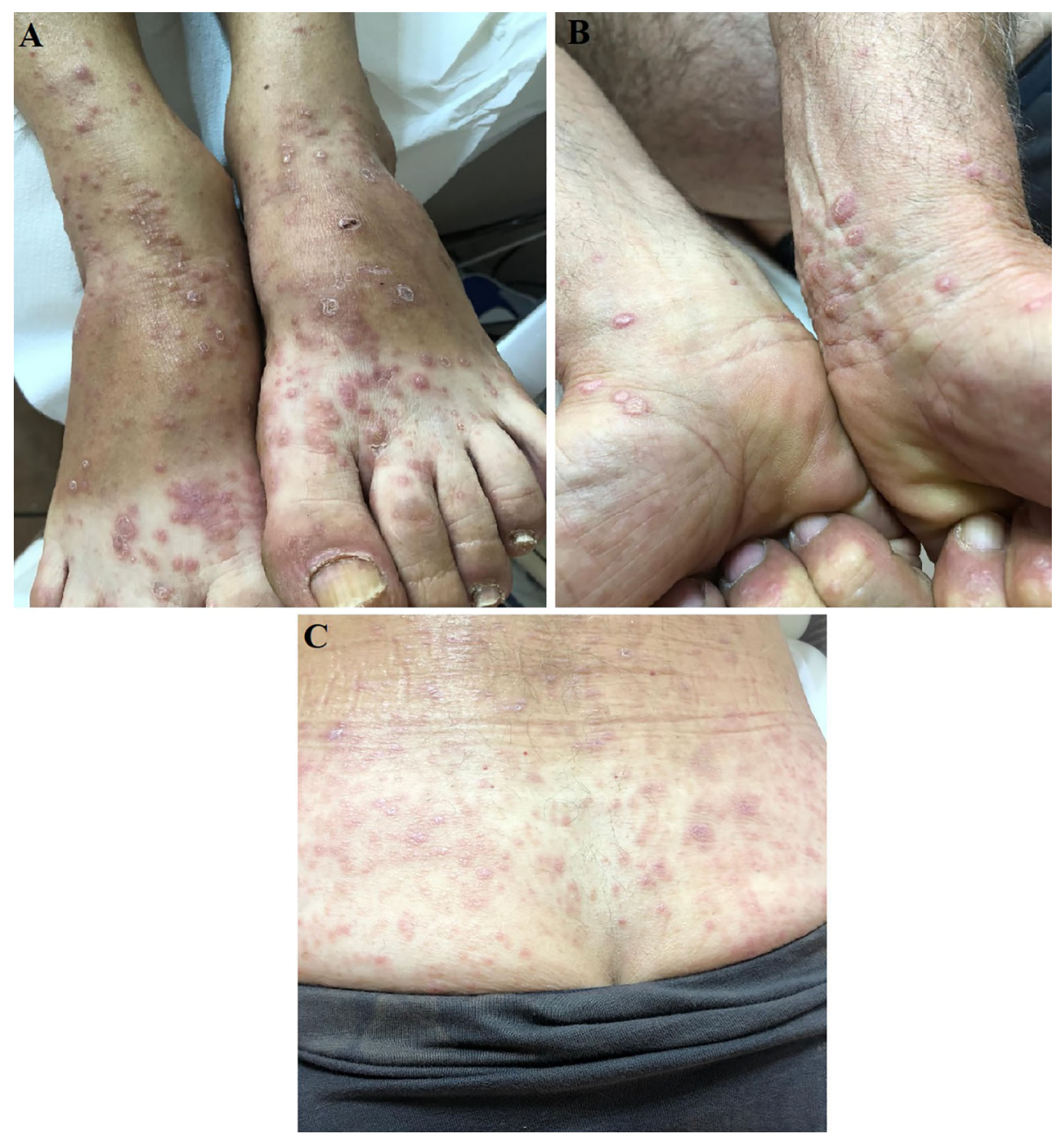

Fig. 1 A Polygonal purpuric papules placed on dorsal region of the feet. B Polygonal purpuric papules placed on flexor region of the wrists. C Polygonal purpuric papules placed on lumbosacral region 


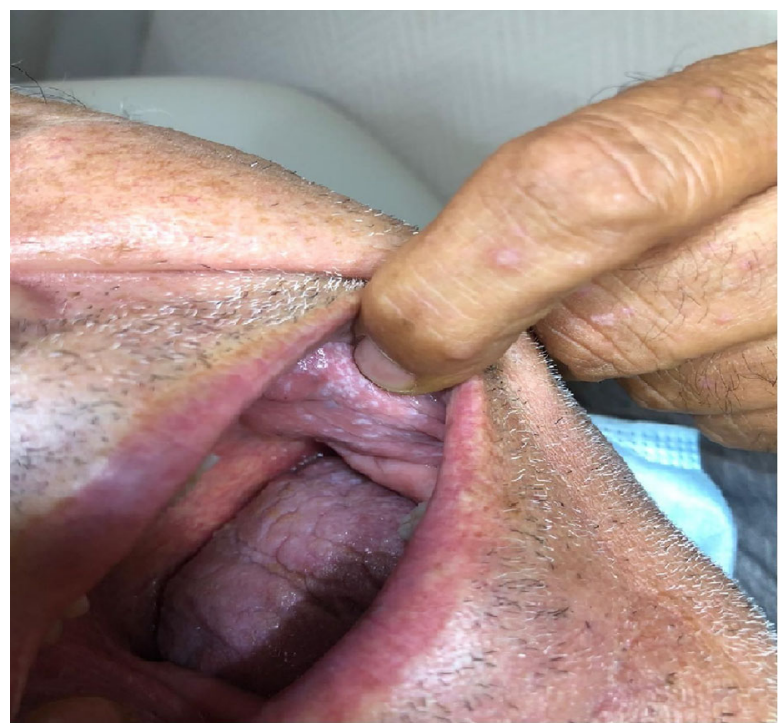

Fig. 2 Oral lichen planus: papular and whitish lesions of the oral mucosa

striae were clearly appreciated. These lesions appeared together at 7 days after the administration of the first dose of Moderna vaccine and immediately presented with an associated intense itchy symptomatology, only partially responsive to antihistamine therapy. Furthermore, on physical examination of the oral mucosa, whitish papular lesions were found, with symmetrical and bilateral distribution (Fig. 2), typical of an oral papular LP [1]. Oral lesions, in contrast to cutaneous lesions, were asymptomatic. Hematochemical examinations allowed us to rule out underlying hepatic involvement and any other infectious diseases. Finally, a skin biopsy was performed to confirm our clinical suspicion of LP. Histologic analysis showed the presence of hyperkeratosis with acanthosis, colliquative degeneration of basal layer cells, and banded lymphocytic infiltrate in the superficial dermis. A diagnosis of a newonset LP was made, and treatment with highpotency topical corticosteroids (clobetasol propionate) and $\mathrm{H}(1)$-anthistaminic therapy (cetirizine $10 \mathrm{mg} /$ daily) for 10 days was started. At the follow-up visit, 15 days after the start of therapy, the patient presented in clinical remission with absence of oral and cutaneous manifestations. Finally, 1 month after the last visit, the patient did not present disease recurrence. The patient gave the consent for photo acquisition and publication. Our manuscript meets the ethical standards according to the Declaration of Helsinki.

\section{DISCUSSION}

LP is an inflammatory dermatosis involving the skin and/or mucous membranes, of unknown etiology mediated by $\mathrm{T}$ lymphocytes. It can be associated with numerous triggers, such as medications, infections (such as Hepatitis C), and vaccines [2]. Moreover, among the latter, the vaccines most frequently associated in the literature with LP are those for influenza and herpes zoster [3]. There are currently few cases in the literature reporting a relationship between COVID-19 vaccination and the occurrence of lichen planus, and most were associated with the Pfizer vaccine or following the administration of vector-based COVID-19 vaccine (Ad26.COV2.S) [4-8]. This is one of the first cases associated with the Moderna vaccine. McMahon et al. [9] performed a registry-based study where they discussed the occurrence of vaccine-related eruption of papules and plaques (V-REPP) after COVID-19 vaccination. Among these skin manifestations, lichen planus was reported in four cases, three of which were related to the Pfizer vaccine and one to the Moderna vaccine. The physiopathological mechanisms underlying the relationship between LP and vaccination for COVID-19 are still poorly understood, however, it has been shown that after such vaccines there can be a stimulation of the immune response of $\mathrm{T}$ helper lymphocytes type 1 (Th1) [10], leading to the stimulation of the production of interleukin (IL)-12, tumor necrosis factor (TNF) $\alpha$, and interferon (IFN) $\gamma$, cytokines involved in the pathogenesis of LP [11]. What emerges from the literature at present, is that COVID-19 vaccines can cause strong T-cell responses [9-11]. The mechanism by which they might elicit immunostimulatory effects, including triggering T-cell-dependent disorders, requires further study. In fact, there are still few data in the literature that support a causal association 
between the pathophysiological mechanism just mentioned and the onset of LP.

\section{CONCLUSION}

Our case suggest that the COVID-19 vaccine might be a trigger for the development of LP [8]. Since LP is a disease of unknown etiology and data currently available on this subject are not sufficient, it is not possible to establish a causal relationship between the two events. In conclusion, given the global administration of these vaccines, in view also of the third dose, we consider this case important for the literature to deepen the topic. Certainly further studies are necessary.

\section{ACKNOWLEDGEMENTS}

Funding. No funding or sponsorship was received for this study or publication of this article.

Authorship. All named authors meet the International Committee of Medical Journal Editors (ICMJE) criteria for authorship for this article, take responsibility for the integrity of the work as a whole, and have given their approval for this version to be published. We thank the participants of the study.

Author Contributions. Each author equally contributed to the conception and the writing of the manuscript.

Disclsosures. Gabriella Fabbrocini acted as a speaker or consultant for Abbvie, Amgen, Eli Lilly, Janssen, Leo-Pharma, Almyrall, Novartis, and UCB. Vincenzo Picone, Lorenzo Martora and Fabrizio Martora have nothing to disclose.

Compliance with Ethics Guidelines. The patient gave the consent for photo acquisition and publication. Our manuscript meets the ethical standards according to the Declaration of Helsinki.
Data Availability. Data sharing not applicable to this article as no datasets were generated or analysed during the current study.

Open Access. This article is licensed under a Creative Commons Attribution-NonCommercial 4.0 International License, which permits any non-commercial use, sharing, adaptation, distribution and reproduction in any medium or format, as long as you give appropriate credit to the original author(s) and the source, provide a link to the Creative Commons licence, and indicate if changes were made. The images or other third party material in this article are included in the article's Creative Commons licence, unless indicated otherwise in a credit line to the material. If material is not included in the article's Creative Commons licence and your intended use is not permitted by statutory regulation or exceeds the permitted use, you will need to obtain permission directly from the copyright holder. To view a copy of this licence, visit http://creativecommons.org/licenses/by$\mathrm{nc} / 4.0 /$.

\section{REFERENCES}

1. Chiang CP, Yu-Fong Chang J, Wang YP, Wu YH, Lu SY, Sun A. Oral lichen planus-differential diagnoses, serum autoantibodies, hematinic deficiencies, and management. J Formos Med Assoc. 2018;117(9):756-65. https://doi.org/10.1016/j. jfma.2018.01.021 (Epub 2018 Feb 19 PMID: 29472048).

2. Husein-ElAhmed H, Gieler U, Steinhoff M. Lichen planus: a comprehensive evidence-based analysis of medical treatment. J Eur Acad Dermatol Venereol. 2019;33(10):1847-62. https://doi.org/10.1111/jdv. 15771 (Epub 2019 Jul 22 PMID: 31265737).

3. Lai YC, Yew YW. Lichen planus and lichenoid drug eruption after vaccination. Cutis. 2017;100(6): E6-20 (PMID: 29360907).

4. Hiltun I, Sarriugarte J, Martínez-de-Espronceda I, Garcés A, Llanos C, Vives R, Yanguas JI. Lichen planus arising after COVID-19 vaccination. J Eur Acad Dermatol Venereol. 2021;35(7):e414-5. https://doi.org/10.1111/jdv.17221 (Epub 2021 Mar 28. PMID: 33724563; PMCID: PMC8250777). 
5. Herzum A, Burlando M, Molle MF, Micalizzi C, Cozzani E, Parodi A. Lichen planus flare following COVID-19 vaccination: a case report. Clin Case Rep. 2021;9(12): e05092. https://doi.org/10.1002/ ccr3.5092 (Published 2021 Dec 7).

6. Merhy R, Sarkis AS, Kaikati J, El Khoury L, Ghosn S, Stephan F. New-onset cutaneous lichen planus triggered by COVID-19 vaccination. J Eur Acad Dermatol Venereol. 2021. https://doi.org/10.1111/ jdv.17504 (Epub ahead of print. PMID: 34236718).

7. Sharda P, Mohta A, Ghiya BC, Mehta RD. Development of oral lichen planus after COVID-19 vaccination-a rare case report. J Eur Acad Dermatol Venereol. 2021. https://doi.org/10.1111/jdv.17718 (Epub ahead of print. PMID: 34606669).

8. Troeltzsch M, Gogl M, Berndt R, Troeltzsch M. Oral lichen planus following the administration of vector-based COVID-19 vaccine (Ad26.COV2.S). Oral Dis. 2021. https://doi.org/10.1111/odi.14025 (published online ahead of print, 2021 Sep 20).
9. McMahon DE, Kovarik CL, Damsky W, et al. Clinical and pathologic correlation of cutaneous COVID-19 vaccine reactions including V-REPP: a registry-based study. J Am Acad Dermatol. 2022;86(1):113-21. https://doi.org/10.1016/j.jaad. 2021.09.002.

10. Sahin U, Muik A, Derhovanessian E, et al. COVID19 vaccine BNT162b1 elicits human antibody and TH1 T cell responses. Nature. 2020;586(7830): 594-9. https://doi.org/10.1038/s41586-020-2814-7 (published correction appears in Nature. 2021 Feb;590(7844):E17).

11. Pietschke K, Holstein J, Meier K, Schäfer I, MüllerHermelink E, Gonzalez-Menendez I, QuintanillaMartinez L, Ghoreschi FC, Solimani F, Ghoreschi K. The inflammation in cutaneous lichen planus is dominated by IFN- $\Upsilon$ and IL-21-A basis for therapeutic JAK1 inhibition. Exp Dermatol. 2021;30(2): 262-70. https://doi.org/10.1111/exd.14226 (Epub 2020 Nov 12 PMID: 33113249). 